\title{
PERANAN TUNTUTAN KERJA DAN SUMBER DAYA KERJA TERHADAP KETERIKATAN KERJA WANITA KARIR
}

\author{
Annisaa Miranty Nurendra \\ Program Studi Psikologi, Universitas Islam Indonesia \\ annisaa.miranty@uii.ac.id.
}

\begin{abstract}
The purpose of this study is to explore the role of job demands, job resources and work engagement among dual career women. The hypotheses to be tested was : 1) there is correlation between job demands and work engagement among dual career women, 2) there is correlation between job resources and work engagement among dual career women, 3) there is moderating effect from job resources at the correlation between job demand and work engagement among dual career women. This tudy engaged 62 woman employee, which have characteristics as married and have been working for minimum 1 years. Job demands and job resources scales are applied at this study, together with the adaptation of Utrecth Work Engagement Scale (UWES). The analysis showed that :1) job demands is not correlated with work engagement, 2$)$ job resources is correlated with work engagement.

Keywords : job demands, job resources, work engagement, dual career women
\end{abstract}

\section{INTISARI}

Tujuan penelitian ini adalah untuk mengeksplorasi peran tuntutan kerja, sumberdaya kerja dan keterikatan kerja pada wanita karir. Hipotesis yang akan diuji dalam penelitian ini adalah : 1) terdapat korelasi antara tuntutan kerja dan keterikatan kerja pada wanita karir, 2) terdapat korelasi antara sumberdaya kerja dengan keterikatan kerja pada wanita karir, 3) sumber daya kerja memiliki efek moderasi pada hubungan antara tuntutan kerja dengan keterikatan kerja pada wanita karir. Responden pada penelitian ini berjumlah 62 orang wanita karir yang memiliki karakteristik telah menikah dan telah bekerja minimal selama 1 tahun. Skala yang digunakan dalam penelitian ini yaitu skala tuntutan kerja, skala sumberdaya kerja dan skala keterikatan kerja yang diadaptasi dari Utrecht Work Engagement Scale (UWES). Hasil analisis menunjukkan : 1) tidak ada korelasi antara tuntutan kerja dan keterikatan kerja pada wanita karir, 2) terdapat korelasi antara sumberdaya kerja dengan keterikatan kerja, 3) sumber daya kerja tidak memiliki efek moderasi pada hubungan antara tuntutan kerja dengan keterikatan kerja.

Kata kunci : tuntutan kerja, sumberdaya kerja, keterikatan kerja, wanita karir

(B)

anyak penelitian menunjukkan bahwa keterikatan kerja (work engagement) memiliki korelasi positif dengan kinerja. Keterikatan kerja terbukti dapat meningkatkan kinerja individu, yang pada akhirnya akan meningkatkan kinerja organisasi. Penelitian dari Halbesleben \& Bowler (2007) menemukan bahwa pekerja dengan keterikatan kerja yang tinggi akan memiliki kemampuan untuk menampilkan kerja yang baik karena mereka dapat mengaktualisasikan potensi dalam diri mereka dengan lebih baik pada berbagai aspek kinerja.

Keterikatan kerja adalah suatu kondisi individu yang berkaitan dengan kerja dimana pekerja merasa termotivasi secara afektif. Ciri keterikatan kerja yaitu adanya semangat (vigor), dedikasi 
(dedication) dan keterserapan (absorption) (Schaufelli \& Bakker, dalam Xanthopolou, dkk, 2009). Vigor dicirikan dengan adanya tingkat energi yang tinggi, resiliensi mental dalam bekerja, adanya kemauan untuk memberikan usaha dalam bekerja, serta ketekunan dalam menghadapi kesulitan. Dedication dicirikan dengan adanya perasaan bahwa pekerjaan adalah sesuatu yang penting, antusias, terinspirasi, bangga dan tertantang dengan pekerjaan yang dimiliki. Sedangkan Absorption dicirikan dengan adanya konsentrasi penuh terhadap pekerjaan, dimana seorang pekerja akan merasakan waktu menjadi berlalu begitu cepat ketika ia bekerja dan ia sulit memisahkan diri dari pekerjaannya. Dimensi ini merupakan adaptasi dari konsep flow dalam bekerja yang dicetuskan oleh Csikzenmihalyi (Albrecht, 2010). Schaufeli (2006) menekankan bahwa sifat keterikatan kerja adalah suatu keadaan kognitif dan afektif yang cenderung menetap dan menyeluruh, yang tidak terfokus pada satu objek, kejadian, individu atau perilaku tertentu, sehingga keterikatan kerja akan berdampak pada sikap dan perilaku individu di tempat kerja secara umum.

Sehubungan dengan penelitian terdahulu mengenai keterikatan kerja, dapat disimpulkan bahwa penting seorang pekerja memiliki karakteristik motivasional tersebut. Akan tetapi tidak semua pekerja mungkin dapat memiliki keterikatan kerja maupun menampilkan kinerja yang baik. Hal ini dapat diakibatkan oleh tantangan dari pekerjaan, individu maupun lingkungan di luar tempat kerja. Salah satu kelompok pekerja yang rentan mengalami hal ini adalah pekerja wanita, terutama yang telah menikah (dual career woman). Berdasarkan penelitian sebelumnya oleh Naido dan Jano (2002) adanya dua peran yang berbeda, yaitu dalam pekerjaan dan rumah tangga, akan menyebabkan konflik pada diri seorang dual career woman sehingga akan mempengaruhi perannya dalam bekerja. Hal ini juga didukung melalui riset yang dilakukan oleh Apperson (Buhali \& Margareta, 2013). Hasil studinya mengungkapkan bahwa pada beberapa tingkatan konflik peran antara pria dan wanita, pekerja wanita mengalami konflik peran pada tingkat yang lebih tinggi dibanding pria. Ini disebabkan karena wanita memandang keluarga merupakan suatu kewajiban utama mereka dan harus mendapatkan perhatian lebih dibandingkan pada peran pekerjaan mereka.

Dalam telaah mengenai keterikatan kerja pada pegawai wanita, dimungkinkan terdapat dua hal yang mempengaruhi, yaitu tuntutan kerja (job demands) dan sumberdaya kerja (job resources). Hal ini dinyatakan dalam Job Demand-Resources Model yang dicetuskan oleh Bakker (2010). Tuntutan kerja adalah segala aspek fisik, psikologis, sosial dan organisasional dari sebuah pekerjaan yang membutuhkan usaha dan keterampilan fisik dan psikis secara berkelanjutan, sehingga membutuhkan pengorbanan fisik dan psikologis tertentu. Contohnya adalah tekanan kerja yang tinggi, kondisi fisik lingkungan kerja yang kurang mendukung, maupun interaksi emosional dengan stakeholders.

Dalam Bakker, Demerouti \& Verbeke (2004) dan Bakker, Demerouti \& Euwema (2005), ditemukan tiga macam tuntutan 
kerja yang sering dialami pekerja, yaitu beban kerja yang tinggi (workload), tuntutan emosional (emotional demands), dan konflik pekerjaan dan rumah tangga (workhome conflict). Beban kerja adalah segala macam tuntutan-tuntutan pekerjaan yang harus dipenuhi oleh seorang pekerja, misalnya seperti tekanan waktu maupun tingkat konsentrasi yang dibutuhkan. Tuntutan emosional adalah kondisi emosi yang dirasakan dan harus dihadapi ketika individu berusaha untuk menyelesaikan pekerjaannya. Tuntutan emosional dapat bersumber dari pekerjaan itu sendiri maupun karena interaksi dengan orangorang yang berhubungan dengan pekerjaan tersebut. Sedangkan konflik rumah tangga dan kerja adalah konflik yang terjadi pada individu karena peran ganda sebagai pekerja dan sebagai anggota keluarga. Bentuk konflik antara pekerjaan dan rumah tangga ada 2, yaitu : urusan pekerjaan mengganggu waktu keluarga atau urusan keluarga mengganggu waktu pekerjaan (Kreitner \& Kinicki, 2010).

Sementara itu, sumberdaya kerja adalah segala aspek fisik, sosial, psikologis dan atau organisasional yang berfungsi dalam mencapai tujuan kerja, serta menstimulasi pengembangan dan pertumbuhan personal (Demerouti, dkk, 2001). Menurut Schaufelli \& Bakker (2004), sumberdaya kerja memiliki potensi motivasi intrinsik karena dapat memfasilitasi perkembangan dan pembelajaran individu. Sumberdaya kerja juga memberikan potensi motivasi ekstrinsik dengan menyediakan fasilitasi yang bersifat instrumental untuk membantu pekerja mencapai tujuan. Penelitianpenelitian sebelumnya menunjukkan bahwa sumberdaya kerja memiliki korelasi positif dengan keterikatan kerja.

Dalam bekerja, individu seringkali menemui kondisi-kondisi yang menekan dalam melakukan pekerjaannya yang bersumber dari tuntutan kerja. Tuntutan kerja dapat berubah menjadi stressor jika dalam menghadapi tuntutan kerja individu memerlukan usaha yang terlalu besar (Meijman \& Mulder, dalam Bakker, 2006). Jika individu memiliki tuntutan kerja yang relatif tinggi, hal ini akan berdampak terhadap kesejahteraan psikologis pegawai (seperti mengalami burnout, ketegangan kerja, dan kurangnya keterlibatan kerja). Banyak penelitian menunjukkan bahwa tuntutan kerja dapat menimbulkan gangguan tidur, kelelahan dan kesehatan yang buruk (Bakker \& Demerouti, 2006). Berdasarkan banyak penelitian, antara lain yang dilakukan oleh Schaufelli, Bakker, \& Van Rhennen (2009), Hakanen, Schaufelli, \& Ahola (2008), Hakkanen, Bakker \& Scahufelli (2006), serta Bakker, Demerouti \& Verbeke (2004), tuntutan kerja secara signifikan akan menimbulkan burnout dan menurunkan keterikatan kerja.

Sumberdaya kerja memiliki hubungan penting dengan keterikatan kerja terutama pada kondisi di mana tuntutan kerja tinggi (Xanthopolou et al, 2009). Sumberdaya kerja mampu menjadi buffer effect tuntutan kerja terhadap burnout. Dibawah tekanan kondisi kerja, pekerja yang memiliki sumberdaya yang tinggi akan lebih mampu mengatasi tuntutan-tuntutan yang tinggi, sebagai hasilnya, mereka memiliki burnout yang lebih rendah (Bakker dalam Xanthopolou, 2007). Sisi motivasional sumberdaya kerja ada pada 
kemampuannya untuk memenuhi kebutuhan dasar manusia, seperti kebutuhan autonomi, kompetensi, dan kebutuhan sosial. Sebagai contoh, umpan balik yang tepat akan mendorong proses pembelajaran, sehingga akan meningkatkan kompetensi kerja. Sedangkan kebebasan mengambil keputusan dan dukungan sosial dapat memenuhi kebutuhan akan autonomi dan sosial. Sumberdaya kerja dapat pula berperan sebagai motivator ekstrinsik karena lingkungan kerja yang menyediakan banyak sumber daya akan mendorong seseorang agar memiliki kemauan untuk mendedikasikan usaha dan kemampuannya terhadap tugas kerja (Bakker \& Demerouti, 2006).

Menurut penelitian dari Xanthopolou dkk, (2009), Bakker \& Demerouti, (2007), sumberdaya kerja yang signifikan dalam pekerjaan adalah autonomi, kemampuan pengawasan, umpan balik kinerja, kesempatan pengembangan personal, dan dukungan sosial. Autonomi adalah sejauhmana pekerjaan memberikan kebebasan dan keleluasaan pada individu dalam melakukan prosedur-prosedur yang diperlukan untuk menyelesaikan pekerjaan (Hackman \& Oldham, dalam Kreitner \& Kinicki, 2010). Kesempatan pengembangan personal adalah sejauhmana pekerjaan memberikan kesempatan bagi individu untuk mempelajari hal-hal baru yang dapat digunakan untuk mengembangkan diri. Sedangkan dukungan sosial adalah persepsi terhadap jumlah bantuan/dukungan yang diperoleh dari hubungan sosial di tempat kerja.

Penelitian-penelitian terdahulu menunjukkan sumberdaya kerja memiliki korelasi dengan keterikatan kerja yang tinggi (Schaufelli, Bakker \& Van Rhennen (2009), Xanthopolou dkk (2009), Hakkanen, Schaufelli \& Ahola (2008), serta Bakker, Demerouti \& Euwema (2005)). Hackman \& Oldham (dalam Xanthopolou dkk, 2009) menemukan bahwa sumberdaya kerja menjadi buffer effects terhadap tuntutan kerja, serta mendorong pekerja untuk mencapai tujuan mereka. Di sisi lain, pekerja pun menjadi lebih berkomitmen dengan pekerjaan mereka, karena mereka dapat mengaktualisasikan diri melalui pekerjaannya.

Penelitian ini bertujuan untuk mengeksplorasi buffer effects sumberdaya kerja terhadap tuntutan kerja pada keterikatan kerja yang dimiliki oleh wanita karir. Oleh karena itu, hipotesis yang ingin diuji adalah : 1) terdapat korelasi antara tuntutan kerja dan keterikatan kerja pada wanita karir, 2) terdapat korelasi antara sumberdaya kerja dengan keterikatan kerja pada wanita karir, 3) sumber daya kerja memiliki efek moderasi pada hubungan antara tuntutan kerja dengan keterikatan kerja pada wanita karir.

\section{METODE PENELITIAN}

\section{Responden Penelitian}

Responden yang diambil datanya berasal dari suatu instansi di Yogyakarta. Jumlah responden yang berhasil dikumpulkan datanya adalah sebanyak 62 orang dengan kriteria: 1) berjenis kelamin wanita, 2) sudah menikah, 3) memiliki masa kerja minimal 1 tahun. 


\section{Metode Pengumpulan Data}

Data dalam penelitian ini dikumpulkan dengan menggunakan skala. Ada 3 macam skala yang akan digunakan dalam penelitian ini, yaitu Skala Tuntutan kerja, Skala Sumberdaya kerja, dan Skala Keterikatan kerja. Keterikatan kerja diukur dengan menggunakan adaptasi dari Utrecht Work Engagement Scale (UWES) versi pendek yang terdiri dari 17 aitem (Schaufelli \& Bakker, 2006). Aspek-aspek yang digunakan adalah semangat, dedikasi dan keterserapan. Skala kedua yaitu Skala Tuntutan kerja yang terdiri dari 3 aspek, sesuai dengan penelitian yang telah dilakukan sebelumnya oleh Bakker, Demerouti \& Verbeke (2004). Aspek yang digunakan adalah : beban kerja, tuntutan emosional dan konflik pekerjaan dan rumah tangga. Masing-masing aspek pada skala ini memiliki 6 aitem. Skala ketiga adalah Skala Sumberdaya Kerja. Dalam penelitian ini, ada 3 aspek sumberdaya kerja yang akan digunakan, sesuai dengan penelitian yang telah dilakukan sebelumnya oleh Bakker, Demerouti \& Euwema (2005) yaitu : autonomi dalam bekerja, kesempatan pengembangan diri, dan dukungan sosial. Setiap aspek pada skala sumberdaya kerja memiliki 6 aitem.

\section{Metode Analisis Data}

Data dianalisis dengan menggunakan analisis regresi. Regresi yang digunakan yaitu regresi berganda untuk mengetahui peran variabel tuntutan kerja dan sumberdaya kerja sebagai variabel bebas untuk keterikatan kerja. Kemudian teknik moderated-regression analysis melalui SPSS digunakan untuk melakukan eksplorasi variabel sumberdaya kerja sebagai moderator pada hubungan antara variabel tuntutan kerja dengan keterikatan kerja. Pada prosedur moderated-regression analysis yang digunakan, peneliti terlebih dahulu mencari variabel interaksi antara variabel tuntutan kerja dan sumberdaya kerja untuk dianalisis efek moderasinya.

\section{HASIL}

Karakteristik demografis dari responden pada penelitian ini yaitu berjenis kelamin wanita, telah menikah dan memiliki masa kerja minimal 1 tahun. Adapun profil deskriptif responden sebagaimana tertampil pada Tabel 1. Dari tabel tampak bahwa mayoritas responden dalam penelitia ini berusia 25-35 tahun yaitu sebanyak 48,4 persen. Sedangkan dar sisi lama bekerja, kelompok responden yang paling banyak adalah kelompok responden yang memiliki masa kerja di bawah 5 tahun, yaitu sebanyak 33,4 persen. Sementara itu responden yang memiliki masa kerja diatas 15 tahun juga cukup banyak yaitu sebesar 30,1 persen. 
Tabel 1. Deskripsi Subjek Penelitian

\begin{tabular}{|c|c|c|}
\hline Karakteristik & Jumlah & Prosentase \\
\hline \multicolumn{3}{|l|}{ Usia } \\
\hline 25 - 35 tahun & 30 & $48,4 \%$ \\
\hline $36-45$ tahun & 18 & $29 \%$ \\
\hline $46-55$ tahun & 13 & $21 \%$ \\
\hline Tidak diketahui & 1 & $1,6 \%$ \\
\hline \multicolumn{3}{|l|}{ Lama Bekerja } \\
\hline$<5$ tahun & 21 & $33,4 \%$ \\
\hline $6-10$ tahun & 9 & $14,5 \%$ \\
\hline $11-15$ tahun & 11 & $17,8 \%$ \\
\hline$>15$ tahun & 19 & $30,1 \%$ \\
\hline Tidak Diketahui & 2 & $3,2 \%$ \\
\hline TOTAL & 62 & $100 \%$ \\
\hline
\end{tabular}

Analisis deskriptif dilakukan lebih variabel keterikatan kerja dan sumberdaya lanjut untuk melihat statistik deskriptif kerja mendekati skor hipotetik maksimum. hasil penelitian. Sebagaimana yang dapat Sementara itu, hanya variabel tuntutan diamati pada tabel 2, sebaran data untuk kerja yang memiliki sebaran cukup luas.

Tabel 2. Deskripsi Statistik Data Penelitian

\begin{tabular}{lcccccccc}
\hline \multicolumn{1}{c}{ Variabel } & \multicolumn{4}{c}{ Skor Hipotetik } & \multicolumn{3}{c}{ Skor Empirik } \\
\cline { 2 - 9 } & Min & Max & Mean & Std. Dev. & Min & Max & Mean & Std. Dev. \\
\hline Keterikatan Kerja & 0 & 102 & 51 & 17 & 40 & 99 & 78,77 & 14,76 \\
Tuntutan Kerja & 13 & 65 & 39 & 8.67 & 14 & 52 & 36,88 & 6,64 \\
Sumberdaya Kerja & 15 & 75 & 45 & 10 & 41 & 73 & 59,16 & 7,24 \\
\hline
\end{tabular}

Berdasarkan analisis kategori data, dapat disimpulkan bahwa sebagian besar responden memiliki skor keterikatan kerja yang berkisar dalam kategori tingi dan sangat tinggi, yaitu total sebanyak 85,5 persen. Skor sumberdaya kerja juga berkisar pada kategori tinggi dan sangat tinggi, dengan jumlah total 87,1 persen dari keseluruhan responden. Sedangkan skor tuntutan kerja justru berkisar pada kategori sedang dengan frekuensi sebanyak 69,4 persen dari jumlah responden.

Tabel 3. Kategorisasi Data Variabel Penelitian

\begin{tabular}{ccccccc}
\hline Kategori & \multicolumn{2}{c}{ Keterikatan Kerja } & \multicolumn{2}{c}{ Tuntutan Kerja } & \multicolumn{2}{c}{ Sumberdaya Kerja } \\
\cline { 2 - 7 } & $\mathbf{N}$ & $\mathbf{\%}$ & $\mathbf{N}$ & $\mathbf{\%}$ & $\mathbf{N}$ & $\mathbf{\%}$ \\
\hline Sangat Tinggi & 30 & 48,4 & 0 & 0 & 14 & 22,6 \\
Tinggi & 23 & 37,1 & 5 & 8,1 & 40 & 64,5 \\
Sedang & 9 & 14,5 & 43 & 69,4 & 8 & 12,9 \\
Rendah & 0 & 0 & 13 & 21 & 0 & 0 \\
Sangat Rendah & 0 & 0 & 1 & 1,5 & 0 & 0 \\
\hline TOTAL & $\mathbf{6 2}$ & $\mathbf{1 0 0}$ & $\mathbf{6 2}$ & $\mathbf{1 0 0}$ & $\mathbf{6 2}$ & $\mathbf{1 0 0}$ \\
\hline
\end{tabular}


Hasil analisis data dengan menggunakan regresi berganda dan moderated regression analysis menunjukkan bahwa : 1) tidak terdapat korelasi antara variabel tuntutan kerja dengan keterikatan kerja ( $>0,05), 2)$ terdapat korelasi yang signifikan antara variabel sumberdaya kerja dengan keterikatan kerja $(\mathrm{p}<0,05)$, dan 3$)$ variabel sumberdaya kerja tidak memiliki efek moderator pada hubungan antara tuntutan kerja dengan keterikatan kerja ( $>0,05)$. Hasil lengkap analisis disajikan pada Tabel 1 .

Tabel 4. Hasil Analisis Data

\begin{tabular}{lcc}
\hline \multicolumn{1}{c}{ Variabel } & R & p \\
\hline Tuntutan Kerja * Keterikatan Kerja & 0.195 & 0.128 \\
Sumberdaya Kerja * Keterikatan Kerja & 0.355 & 0.018 \\
Tuntutan Kerja * Sumberdaya Kerja * Keterikatan Kerja & 0.355 & 0.870 \\
\hline
\end{tabular}

\section{PEMBAHASAN}

Secara spesifik, penelitian ini tidak sesuai dengan beberapa penelitian terdahulu mengenai buffer effects sumber daya kerja terhadap tuntutan kerja (antara lain Bakker, Demerouti, \& Euwema, 2005). Salah satu indikasi penyebabnya adalah karena tidak terdapat korelasi yang signifikan antara tuntutan kerja dengan keterikatan kerja. Skor rata-rata tuntutan kerja pada responden ini tergolong sedang, sementara itu skor keterikatan kerja secara rerata tergolong tinggi. Besarnya korelasi antara tuntutan kerja dengan keterikatan kerja pada penelitian ini adalah sebesar $r=$ 0,195 dengan sumbangan efektif sebesar 19,5\%. Hal ini dapat berarti ada variabel lain yang memiliki korelasi lebih kuat dengan variabel keterikatan kerja.

Hasil analisis lebih lanjut menunjukkan bahwa variabel sumberdaya kerja ternyata memiliki korelasi langsung yang signifikan dengan variabel keterikatan kerja. Sumberdaya kerja tidak memiliki efek moderasi terhadap hubungan antara tuntutan kerja dengan keterikatan kerja pada wanita karir. Hal ini sesuai permodelan Job-Demands Resources (JDR) yang dikemukakan oleh Bakker (2007), dimana sumberdaya kerja tidak sekedar memiliki peran untuk mengimbangi tuntutan kerja tetapi juga memiliki peran signifikan sendiri.

Sumberdaya kerja memiliki potensi motivasional dan mendorong pada keterikatan kerja yang tinggi. Potensi motivasi yang dimiliki sumberdaya kerja ada 2, yaitu potensi motivasi intrinsik dan ekstrinsik. Sumberdaya kerja memiliki peran sebagai motivator intinsik karena sumberdaya kerja mendorong perkembangan, pertumbuhan dan pembelajaran individu. Adapun peran sumberdaya kerja sebagai motivator ekstrinsik karena bersifat instrumental dalam pencapaian tujuan kerja.

Sumberdaya kerja memenuhi kebutuhan dasar manusia, seperti kebutuhan akan autonomi, kompetensi, dan keterhubungan dengan hal-hal di luar dirinya (relatedness). Sebagai contoh, umpan balik yang tepat akan mendorong proses pembelajaran, sehingga akan meningkatkan kompetensi kerja, sedangkan kebebasan 
mengambil keputusan dan dukungan sosial dapat memenuhi kebutuhan akan autonomi dan kebutuhan untuk memiliki (needs of belongingness). Sumberdaya kerja dapat pula berperan sebagai motivator ekstrinsik karena lingkungan kerja yang menyediakan banyak sumber daya akan mendorong seseorang agar memiliki kemauan untuk mendedikasikan usaha dan kemampuannya terhadap tugas kerja (Bakker \& Demerouti, 2006).

Potensi motivasi intrinsik terdapat pada sumber daya kerja karena sumberdaya kerja dibutuhkan untuk beradaptasi dengan tuntutan kerja dan untuk mencapai tujuan pekerjaan. Hal ini berhubungan dengan pandangan bahwa pemuasan terhadap kebutuhan psikologis yang bersifat mendasar terhadap otonomi, rasa memiliki (belongingness), kompetensi, serta sumberdaya kerja secara intrinsik akan memotivasi pegawai (Van den Broeck, dalam Albrecht, 2010). Penelitian Xanthopolou (2007) menunjukkan bahwa pekerja yang memiliki sumberdaya kerja yang tinggi akan menggunakan kemampuan yang dimilikinya sehingga mereka lebih mampu mengatasi tuntutan kerja yang tinggi.

Proses motivasi intrinsik tersebut juga sesuai dengan Job Characteristic Theory. Hackman \& Oldham (dalam Kreitner \& Kinicki, 2010) berpendapat bahwa pekerjaan dapat dirancang sedemikian rupa sehingga dapat memotivasi karyawan secara internal atau intrinsik. Motivasi intrinsik terjadi ketika individu terlibat ke dalam pekerjaannya karena adanya perasaan positif yang menyebabkan individu bekerja dengan baik untuk dapat bekerja secara efektif, bukan karena tergantung oleh faktor-faktor eksternal. Hackman \& Oldham lebih lanjut menjelaskan, motivasi kerja internal dipengaruhi oleh tiga keadaan psikologis dimana ketiga keadaan tersebut akan dipengaruhi oleh lima inti dimensi pekerjaan. Karena itu, untuk menciptakan motivasi internal yang tinggi, maka pekerjaan harus dirancang agar memiliki kelima dimensi tersebut (Kreitner \& Kinciki, 2010). Lima dimensi motivasional tersebut adalah otonomi, dukungan sosial, kemampuan pengawasan, umpan balik terhadap kinerja, dan kesempatan untuk pengembangan profesional. Penelitian yang dilakukan oleh Xanthopoulou (2009) menunjukkan kelima dimensi tersebut memiliki korelasi positif dengan keterikatan kerja. Dampak dari dimensi sumberdaya kerja adalah pekerja pun menjadi lebih berkomitmen dan terikat dengan pekerjaan mereka, karena mereka mendapatkan aktualisasi diri dari pekerjaannya (Bakker \& Demerouti, 2006). Schaufelli, Bakker \& Van Rhennen (2009), Xanthopolou dkk (2009), Hakkanen, Schaufelli \& Ahola (2008), serta Bakker, Demerouti \& Euwema (2005).

\section{SIMPULAN DAN SARAN}

\section{Simpulan}

Hasil penelitian ini menunjukkan bahwa tuntutan kerja tidak berkorelasi dengan keterikatan kerja pada wanita karir. Sumberdaya kerja berkorelasi secara signifikan dengan keterikatan kerja pada wanita karir. Akan tetapi sumberdaya kerja tidak memiliki efek moderasi pada hubungan antara tuntutan kerja dengan keterikatan kerja pada wanita karir. 


\section{Saran}

Penelitian ini menggunakan responden yang masih terbatas, oleh karena itu penelitian selanjutnya perlu melibatkan subjek yang lebih banyak. Selain itu perlu dieksplorasi pula faktor-faktor apa sajakah yang mempengaruhi dinamika keterikatan kerja pada wanita karir. Dengan demikian nantinya dapat dirumuskan model kebijakan organisasi yang tepat untuk mendukung optimalisasi peran dan kinerja wanita karir dalam organisasi.

\section{DAFTAR PUSTAKA}

Albrecht, S. (2010). Handbook of Employee Engagement : Perspectives, Issues, Research and Practice. UK : Edward Elgar Publishing.

Bakker,A., Schaufeli, W., Leiter, M., \& Taris, T. (2008). Work Engagement: An emerging concept in occupational health psychology. Work \& Stress, 22(3), 187-200.

Bakker, A., Demerouti, E., Hakanen, J., \& Xanthopolou, D. (2007). Job resources boost work engagement, particularly when job demands are high. Journal of Educational Psychology, 99(2),274284

Bakker, A. \& Demerouti, W. (2006). The Job Demands-Resources Model: State of The Art. Journal of Managerial Psychology, 22(3),309-328

Bakker, A., Demerouti,E., \& Euwema, M. (2005). Job Resources Buffer the Impact of Job demands on Burnout. Journal of Occupational Health Psychology, 10(2) 170-180
Bakker, A., Demerouti, E. \& Verbeke, W. (2004). Using The Job demandsResources Model to Predict Burnout and Performance. Human Resource Management, 43(1),83-104.

Christian, M., Garza, A., \& Slaughter, J. (2011). Work engagement : A Quantitative Review and Test of Its Relations with Task and Contextual Performance. Personnel Psychology, 64, 89-136

Gonzales-Roma, V., Schaufeli W., Bakker, A., LLoret, S. (2006). Burnout and Work engagement : Independent Factors or Opposite Poles? Journal of Vocational Behavior 68,165-174.

Hakanen,J., Schaufelli,W., \& Ahola, K. (2008). The Job demands-resources Model: A three-years Cross Lagged Study of Burnout, Depression, Commitment, and Work engagement. Work \& Stress, 22(3), 224-241

Hakanen,J. Bakker, A., \& Schaufeli, W. (2006). Burnout and Engagement among Teachers. Journal of School Psychology, 43, 495-513

Halbesleben, J. \& Wheeler, A. (2008). The Relative Roles of Engagement and Embededness in Predicting Job Performance and Intention to Leave. Work \& Stress, 22(3), 242-256

Hallberg U, Johannson G., \& Schaufeli W. (2007). Type A behavior and work Situation : association with Burnout and Work Engagement. Scandinavian Journal of Psychology, 48, 135-142

Hermsen, J. \& Rosser, V. (2008). Examining Work engagement and Job Satisfaction of Staff Members in 
Higher Education. CUPA-HR Journal, Fall/Winter 2008.

Kreitner, R. \& Kinicki, A. (2010). Organizational Behavior, 9th Edition. New York : McGraw-Hill.

Miller, M., Woehr, D., \& Hudspeth, N. (2001). The Meaning and Measurement of Work Ethic : Construction and Initial Validation of a Multidimensional Inventory. Journal of Vocational Behavior 59, 1-39

Rothmann, S. \& Joubert, J. (2007). Job demands, Job Resources, Burnout \& Work engagement of Managers at a Platinum Mine in the North West Province. South Africa Journal of Bussiness Management, 38 (3)

Salanova, M., Agut, A., \& Peiro, J. (2005). Linking Organizational Resources and Work engagement to Employee Performance and Customer Loyalty : The Mediation of Service Climate. Journal of Applied Psychology, 90(6), 1217-1227

Salanova, M. \& Schaufeli, W. (2008). A Cross-National Study of Work engagement as A Mediator between Job Resources and Proactive Behavior. The International Journal of Human Resource Management, 19(1), 116-131

Schaufeli, W., Bakker, A.,\& Van Rhennen, W. (2009). How Changes in Job demands and Resources Predict Burnout, Work engagement, and Sickness Absenteeism. Journal of Organizational Behavior, 30, 893-917

Schaufelli, W. \& Bakker, A. (2006). The Measurement of Work engagement with a Short Questionnaire: A Cross-
Nastional Study. Educational and Psychological Measurement, 66(4), 701-716

Schaufeli, W. \& Bakker, A. (2004). Job demands, Job resources and their relationship with burnout and engagement : a multi-sampel study. Journal of Organizational Behavior. $25,293-315$

Schaufeli, W. \& Salanova, M. (2007). Efficacy or Inefficacy, That's the Question: Burnout and Work engagement, and Their Relationship with Efficacy Beliefs. Journal of Anxiety, Stress \& Coping, June 2007, 20(2), 177-196

Seppala, P., Mauno, S., Feldt, T. Hakanen, J., \& Schaufeli, W. (2009). The Construct Validity of The Utrecht Work engagement Scale : Multisample and Longitudinal Evidence. Journal of Happiness Studies. 10 : 459-481.

Sonnentag S., Mojza, E., Bienniwes, C., \& Scholl, A. (2008). Being Engaged at Work and Detached at Home: A Week Level Study in Work engagement, Psychological Detachment and Affect. Work \& Stress, 22(3), 257-276

Xanthopolou, D., Bakker, A., Demerouti, E., \& Schaufeli, W. (2009a). Reciprocal Relationship between Job Resources, Personal resources and Work engagement . Journal of Vocational Behavior, 74, 235-244.

Xanthopolou, D., Bakker, A., Demerouti, E., \& Schaufeli, W. (2009b). Work engagement and Financial Returns : A diary Study on The Role of Job and Personal resources. Journal of Occupational and Organizational Psychology, 82, 183-200 
Xanthopolou, D. Bakker, A., Demerouti, E., \& Schaufeli, W. (2007). The Role of Personal resources in The Job
demands-Resources Model. International Journal of Stress Management, 14(2), 121-141 